\title{
ANALISIS PENERAPAN LEAN SERVICE UNTUK MENGURANGI WASTE PADA ORDER FULFILLMENT DI PLB PT AGILITY INTERNATIONAL (SEMARANG)
}

\author{
Dr Erna Mulyati, S.T., MT ${ }^{1}$,Haniva Rananisa ${ }^{2}$, \\ ${ }^{1}$ Program Studi D IV Logistik Bisnis, Politeknik Pos Indonesia \\ Email: rna_rian@yahoo.com \\ ${ }^{2}$ Program Studi D IV Logistik Bisnis, Politeknik Pos Indonesia \\ Email: varanisa27@gmail.com
}

\begin{abstract}
Abstrak
PLB PT Agility International (Semarang) menyediakan jasa pergudangan untuk memenuhi kebutuhan industri manufaktur otomotif yaitu Semarang Autocomp Manufacturing Indonesia (SAMI). Layanan jasa pergudangan yang dilakukan Agility meliputi inbound, storage, order fulfillment, dan outbound. Permasalahan yang terjadi adalah keterlambatan pengiriman yang disebabkan oleh lamanya waktu pemenuhan order. Terdapat pemborosan (waste) dari non value added activity selama proses order fulfillment. Oleh karena itu, diperlukan metode yang dapat mengeliminasi pemborosan tersebut, yaitu pendekatan lean service. Perusahaan diharapkan mampu meningkatkan nilai tambah (value added) terhadap pemborosan dengan menggunakan Metode Lean Service. Proses order fulfillment yang ada dipetakan dengan Value Stream Mapping melalui analisa hasil kuesioner seven waste.

Berdasarkan hasil Metode Waste Assessment Model (WAM) didapatkan persentase waste terbesar adalah waste duplication dengan persentase sebesar 12,07\% dan waste transportation dengan persentase sebesar 9,50\%. Waste dengan persentase terbesar merupakan waste kritis (paling berpengaruh) yang terjadi pada proses order fulfillment PLB PT Agility International. Hasil dari skor WAM dianalisa dengan 5 Why's Analysis untuk mencari akar peyebab pemborosan. Total aktivitas setelah di eliminasi menjadi 24 aktivitas dari 34 aktivitas. Pada Current State Mapping, rata-rata waktu yang dibutuhkan dalam keseluruhan proses order fulfillment sebesar 427,95 menit, sedangkan pada Future State Mapping setelah perbaikan adalah sebesar 280,03 menit.
\end{abstract}

Kata Kunci: Lean service, Value Stream Mapping, value added, necessary but non-value added, non-value added.

\section{PENDAHULUAN}

Perusahaan yang bergerak di bidang manufaktur umumnya membutuhkan bahan baku dalam proses produksi. Kebutuhan bahan baku harus dipenuhi agar proses produksi dapat berjalan dengan baik. Saat ini kebutuhan bahan baku, barang modal, dan bahan penolong untuk industri domestik, masih banyak diimpor dari gudang penimbunan di negara tetangga, yaitu Singapura dan Malaysia, yang mengakibatkan biaya dan waktu menjadi tidak efisien. Berbagai upaya telah dilakukan oleh pemerintah untuk menekan biaya logistik, salah satunya pengembangan Pusat Logistik Berikat (PLB).

PLB PT Agility International (Semarang) merupakan salah satu perusahaan yang melayani jasa pergudangan untuk perusahaan manufaktur otomotif yaitu Semarang Autocomp Manufacturing Indonesia (SAMI). Aktivitas pergudangan di Agility meliputi kegiatan inbound, storage, order fulfillment dan outbound. Order fulfillment meliputi proses replenish, picking, scan, pengecekan material, pembuatan invoice, persiapan loading dan proses loading.

Terjadi keterlambatan pengiriman yang disebabkan oleh lamanya waktu pemenuhan order. Lamanya waktu pemenuhan order disebabkan oleh barang yang tidak ditemukan di lokasi penyimpanan, terjadi kesalahan dalam proses scan, dan terjadi aktivitas menunggu. Dalam usaha peningkatan produktivitas untuk menurunkan waktu pemenuhan order perusahaan harus mengetahui kegiatan-kegiatan yang dapat menurunkan waktu atau aktivitas yang tidak memberikan nilai tambah (non value added). Kegiatan yang tidak memberikan nilai tambah seperti kegiatan yang termasuk ke dalam jenis delay misalnya picker menunggu PTF dan replenish form dari leader, cetak invoice tertunda akibat kesalahan pengambilan barang, dan lain lain. Aktivitas yang bernilai tambah adalah aktivitas yang termasuk ke dalam jenis operasi, 
misalnya admin order melakukan generate data, dan picker mengambil material. Sedangkan aktivitas penting namun tidak bernilai tambah adalah aktivitas yang termasuk ke dalam jenis transportasi dan inspeksi, misalnya picker menuju ke rak penyimpanan, PIC order melakukan pemeriksaan pekerjaan picker, dan sebagainya.

VSM sudah sering digunakan dalam memetakan aliran material dan informasi yang menggambarkan representasi suatu proses dari implementasi lean untuk mengidentifikasi proses yang bernilai tambah, tidak bernilai tambah, maupun aktivitas yang tidak bernilai tambah namun diperlukan. Hudori M. (2016) melakukan penelitian yang menerapkan konsep value stream mapping (VSM) yang ada di dalam Lean Service untuk mengidentifikasi dan mengeliminasi waste yang terjadi pada proses receiving dari tahap bongkar hingga pemindahan barang dari lokasi lama ke lokasi yang baru (bin change system). Waktu bin change dapat diminimalisir dengan menggunakan kembali form lokasi kosong. Handayani dan Renaldi (2018) juga melakukan penelitian tentang analisis waste pada proses unloading kayu log dengan pendekatan Lean Service mengunakan metode value stream mapping untuk mengidentifikasi jenis waste terbesar dan paling berpengaruh terhadap proses pembongkaran (unloading) kayu log. Hasil dari penelitian tersebut dapat diketahui jenis waste yang paling berpengaruh dan memiliki tingkat urgensi paling tinggi adalah waiting time.

Secara umum, perbedaan rancangan penelitian yang peneliti usulkan dengan penelitian terdahulu terletak pada pendekatan metode perbaikan yang digunakan. Pada umumnya penelitian terdahulu hanya menggunakan pendekatan metode perbaikan fishbone analysis, tetapi dalam penelitian ini penulis akan menggunakan pendekatan Metode Kaizen dalam usulan perbaikan. Tujuan penelitian ini adalah untuk mengidentifikasi aktivitasaktivitas yang ada pada proses order fulfillment yang bernilai tambah, tidak bernilai tambah, maupun yang tidak bernilai tambah namun diperlukan. Selain itu mengidentifikasi waste dan waste kritis (paling berpengaruh) pada order fulfillment serta melakukan perbaikan untuk meminimalisir waste pada proses orderfulfillment.

\section{METODE PENELITIAN}

Penelitian ini diawali dengan mempelajari kondisi perusahaan dan menganalisis permasalahan yang terjadi di PLB PT Agility International (Semarang) dengan mengidentifikasi dari aliran aktivitas-aktivitas yang terkait proses penerimaan order, replenish, picking, pengecekan material, persiapan loading dan loading. Selanjutnya dilakukan perumusan untuk memudahkan identifikasi masalah dan merumuskan masalah secara jelas sehingga dapat ditentukan tujuan dari penelitian. Lean Service berfokus pada identifikasi dan eliminasi aktivitasaktivitas yang tidak bernilai tambah (non value added activities) dalam operasi (bidang jasa), yang berkaitan langsung dengan pelanggan (Gaspersz, 2007).

Value stream mapping (VSM) adalah salah satu tools dari Lean Services untuk mengidentifikasi aktivitas value added dan nonvalue added pada industri manufaktur sehingga mempermudah untuk mencari akar permasalahan pada proses (McWilliams \& Tetteh, 2008). Metode VSM memiliki keterkaitan dengan Metode Waste Assesment Models (WAM). Metode WAM merupakan metode usulan yang mengartikulasikan definisi masing-masing ketujuh tipe pemborosan dan dampaknya. Metode ini ditujukan untuk membantu melihat pemborosan yang terjadi serta mengukur hubungan dan dampak antar waste pada proses (Rawabdeh, 2005). Penggabungan kedua metode tersebut dapat membantu dalam melakukan analisis jenis waste yang berpengaruh penting atau tidak terhadap waste lainnya pada aliran proses order fulfillment yang sudah dipetakan.

Selanjutnya adalah melakukan pengumpulan data baik data sekunder aktivitas order fulfillment maupun data primer yang diperoleh melalui pengamatan terhadap aktivitas order fulfillment dan melalui kuesioner yang telah disebar kepada Manajer Warehouse Area, Manajer Operasional dan Assisten Manajer untuk selanjutnya dilakukan analisis jenis pemborosan (waste) terbesar berdasarkan hasil kuesioner. Selanjutnya, data yang telah dikumpulkan diolah untuk menjadi input untuk memetakan masalah dan penyelesaian masalah.

\section{HASIL DAN PEMBAHASAN \\ 3.1 Menghitung Waktu Standar}

Dalam menghitung waktu standar menggunakan Metode Time Study. Penghitungan waktu standar dilakukan dengan pengamatan sebanyak 20 kali pada setiap proses order fulfillment dengan menggunakan stopwatch saat melakukan pengukuran. Selanjutnya menentukan rata-rata subgrup untuk setiap kegiatan yang diukur, menghitung rata-rata dari subgrup, menghitung simpangan baku dari waktu penyelesaian, menghitung simpangan baku dari 
harga rata-rata subgrup, menghitung Batas Kendali Atas (BKA) dan Batas Kendali Bawah (BKB), dan melakukan uji kecukupan data. Sehingga dapat diketahui waktu siklus, waktu normal dan waktu standar (baku) pada setiap proses orderfulfillment. Berikut ini merupakan data waktu siklus, waktu normal dan waktu standar:

Tabel 1 Data waktu siklus, waktu normal dan waktu baku.

\begin{tabular}{|c|l|c|c|c|}
\hline \multirow{2}{*}{ No } & \multicolumn{1}{|c|}{ Proses } & $\begin{array}{r}\text { Waktu } \\
\text { Siklus }\end{array}$ & $\begin{array}{r}\text { Waktu } \\
\text { Normal }\end{array}$ & $\begin{array}{c}\text { Waktu Standar } \\
\text { (Waktu Baku) }\end{array}$ \\
\hline 1 & Penerimaan Order & 39,25 & 41,21 & 51,31 \\
\hline 2 & Replenish & 34,08 & 34,08 & 43,12 \\
\hline 3 & Pengambilan material (Picking) & 41,46 & 41,46 & 48,51 \\
\hline 4 & Scan & 9,90 & 9,99 & 12,04 \\
\hline 5 & Pengecekan Material & 32,34 & 33,63 & 40,02 \\
\hline 6 & Pembuatan Invoice & 27,52 & 29,45 & 35,49 \\
\hline 7 & Persiapan Loading & 45,90 & 47,73 & 56,08 \\
\hline 8 & Loading & 19,25 & 20,02 & 23,83 \\
\hline
\end{tabular}

Data waktu siklus dan waktu standar pada Tabel 1 akan digunakan sebagai input untuk membuat Current State Map

\subsection{Membuat Current State Map (CSM)}

Penggambaran Value Stream Mapping dapat dilakukan dengan melihat aliran proses operasi order fulfillment. Pada tahap ini setiap proses sepanjang value stream digunakan dengan aliran material dan informasi sehingga menjadi satu kesatuan aliran dalam proses order fulfillment di PLB PT Agility International. Langkah-langkah dalam pembuatan peta untuk setiap kategori proses yaitu meletakkan nama proses dibagian atas process box, melengkapi process box dengan data waktu standar, memasukkan jumlah operator pada proses tersebut, memasukkan lead time proses sebagai non value added time di depan process box dan waktu standar sebagai value added time di bawah process box. selanjutnya pada tahap ini setiap proses sepanjang value stream digabungkan dengan aliran material dan aliran informasi sehingga menjadi satu kesatuan aliran proses order fulfillment. Berikut ini penggambaran Current State Map (CSM) pada order fulfillment:

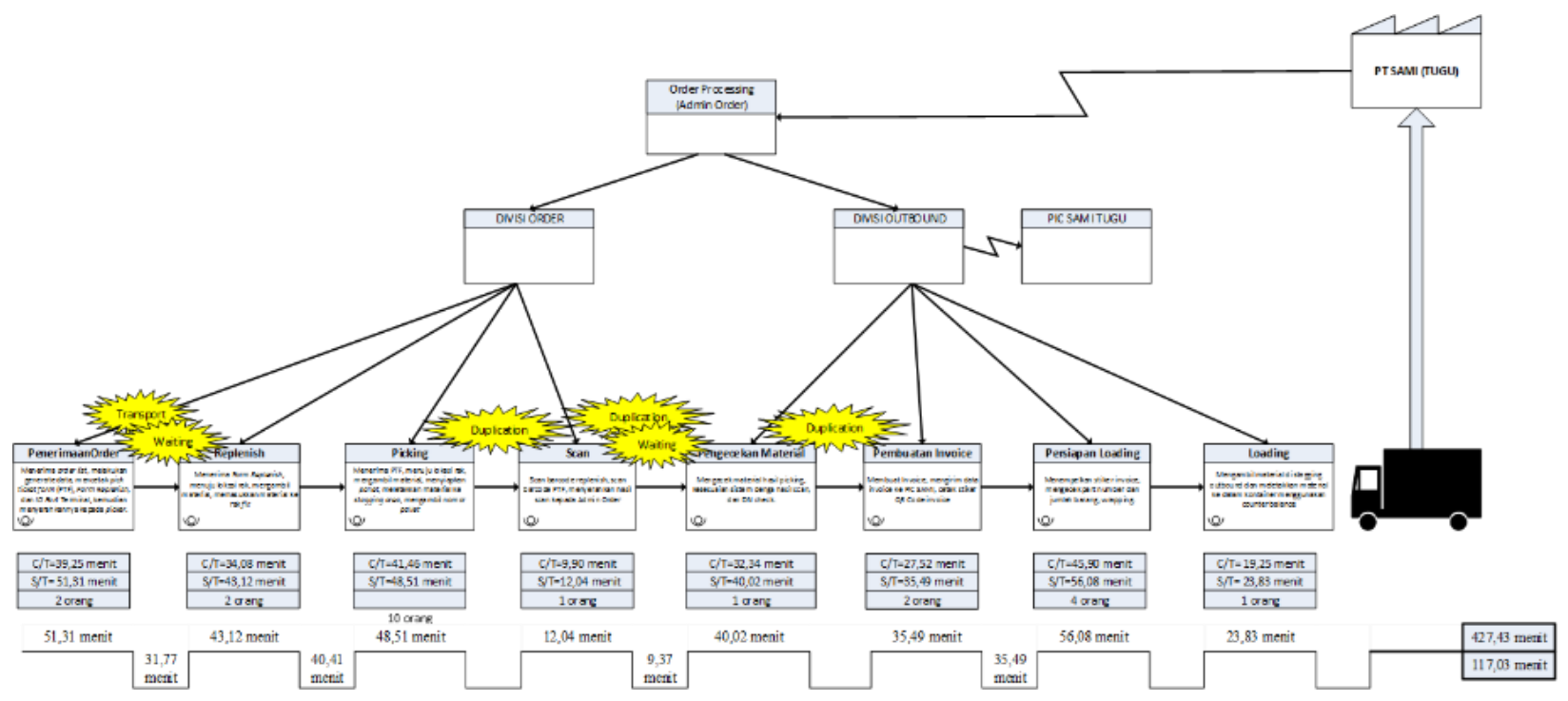

Gambar 1 Curent State Map (CSM) Pada Proses Order Fulfillment

Berdasarkan CSM, kemudian dilakukan process activity mapping yang akan memberikan gambaran aliran fisik dan informasi, waktu yang diperlukan untuk setiap aktivitas. Pengelompokan waktu dilakukan berdasarkan jenis kegiatan dengan menjumlahkan aktivitasaktivitas yang tidak memberi nilai tambah kepada produk seperti terlihat pada Gambar 2: 


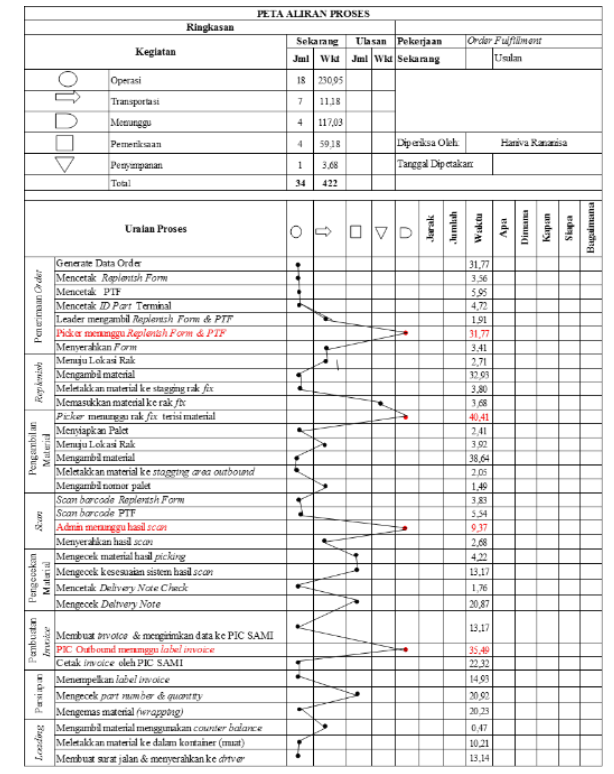

\section{Gambar 2 Peta Aliran Proses Order Fulfillment}

Aktivitas yang termasuk ke dalam jenis operasi merupakan aktivitas yang bernilai tambah (value added), untuk aktivitas yang termasuk ke dalam jenis tranportasi, dan inspeksi merupakan aktivitas penting tapi tidak bernilai tambah, sedangakan delay adalah aktivitas yang dihindari untuk terjadi sehingga merupakan aktivitas berjenis tidak bernilai tambah (non value added).

\subsection{Melakukan Identifikasi dan}

\section{Pengukuran Waste}

Identifikasi dan pengukuran waste menggunakan metode Waste Assessment Model (WAM) yang terdiri dari tiga tahapan yaitu Seven Waste Relationship (SWR), Waste Relationship Matrix (WRM) dan Waste Assessment Questionnaire (WAQ). Hasil Rata-rata Konversi Waste Matrix Value dari 3 Responden adalah:

Tabel 2 Hasil Rata-rata Konversi Waste Matrix Value dari 3 Responden

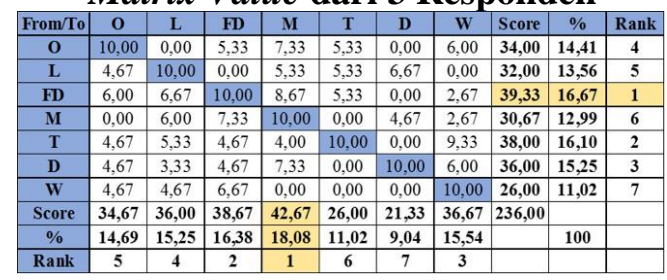

Dapat diketahui jumlah skor dari masingmasing waste yang diperoleh berdasarkan jawaban dari ke 3 responden. Nilai from failure demand mempunyai persentase tertinggi sebesar $16,67 \%$ selanjutnya transportation sebesar $16,10 \%$. Hal ini menunjukkan bahwa from failure demand dipengaruhi oleh waste lainnya. Sedangkan nilai to motion memiliki persentase tertinggi sebesar $18,08 \%$, selanjutnya waste failure demand sebesar 16,38\%. Hal ini menunjukkan bahwa to motion paling banyak mempengaruhi untuk menyebabkan terjadinya waste lain. Sedangkan Rata-rata dan Rekapitulasi hasil Waste Assessment Questionnaire dari 3 Responden dapat dilihat pada Tabel 3 dan Gambar 3:

Tabel 3 Rata-rata hasil Waste Assessment Questionnaire dari 3 Responden

\begin{tabular}{|c|c|c|c|c|c|c|c|}
\hline \multicolumn{8}{|c|}{ Responden } \\
\hline & $\begin{array}{c}\text { Over } \\
\text { production }\end{array}$ & \begin{tabular}{c|} 
Lack of \\
Standarization
\end{tabular} & \begin{tabular}{|l|} 
Failure \\
Demand
\end{tabular} & \begin{tabular}{|l} 
Move \\
ment
\end{tabular} & Transportation & Duplication & Waiting \\
\hline Score (Yj) & 0,18 & 0,15 & 0,20 & 0,17 & 0,15 & 0,16 & 0,20 \\
\hline Pj Factor & 208,72 & 20334 & 274,03 & 236,38 & 178,00 & 136,33 & 171,87 \\
\hline $\begin{array}{c}\text { Final Result } \\
\text { (X) finaly) }\end{array}$ & 37,47 & 30,87 & 54,93 & 39,87 & 27,13 & 22,58 & 3,61 \\
\hline Final Result $(e \mathrm{~d}$ & 651 & 8,33 & 4,47 & 6,15 & 9,50 & 12,07 & 7,03 \\
\hline Rank & 5 & 3 & 7 & 6 & 2 & 1 & 4 \\
\hline
\end{tabular}

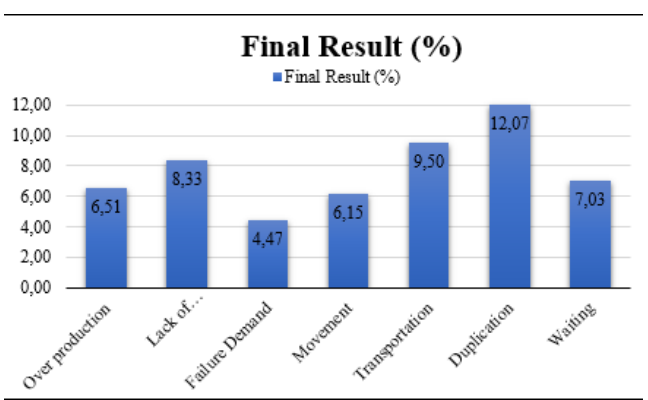

Gambar 3 Rekapitulasi Rata-rata hasil Waste Assessment Questionnaire dari 3 Responden

\subsection{Analisis Penyebab Timbulnya Waste}

Berdasarkan hasil dari WAQ didapatkan 2 waste yang paling dominan terjadi yaitu waste duplication dan transportation. Dua jenis waste inilah yang akan dilakukan penyusunan solusi langkah perbaikan. Faktor-faktor penyebab terjadinya waste kritis tersebut kemudian diidentifikasi di setiap tahapan proses dengan menggunakan Why-why analysis (5 why's analysis). 
Tabel 4 Five Why's Analysis Pemborosan Duplication

\begin{tabular}{|c|c|l} 
No & Metode 5 Why & Permasalahan: Pemborosan Duplication \\
\hline 1 & Why & PIC Outbound mengecek ulang data pada sister \\
\hline 2 & Why & Terjadi kesalahan dalam input data saat proses $s$ \\
\hline 3 & Why & $\begin{array}{l}\text { Pengambilan material yang tidak sesuai den } \\
\text { PTF }\end{array}$ \\
\hline 4 & Why & Kesalahan membaca ID Part Pada Material \\
\hline 5 & Why & Terdapat similar part pada material \\
\hline
\end{tabular}

Tabel 5 Five Why's Analysis Pemborosan Transportation

\begin{tabular}{|c|c|l|}
\hline No & Metode 5 Why & Permasalahan: Pemborosan Transportation \\
\hline 1 & Why & $\begin{array}{l}\text { Leader berjalan dari office menuju lokasi } \\
\text { administrasi } \text { outbound untuk menyerahkan PTF dan } \\
\text { replenish form kepada picker. }\end{array}$ \\
\hline 2 & Why & PTF dan replenish form belum dicetak. \\
\hline 3 & Why & Terjadi keterlambatan generate data order \\
\hline 4 & Why & PTF dan replenish tidak disiapkan pada akhir shift. \\
\hline 5 & Why & Kurang komunikasi antar shift. \\
\hline
\end{tabular}

Hasil eliminasi per aktivitas pada proses order fulfillment dapat dilihat pada Tabel 6 berikut
Tabel 6 Hasil Eliminasi per Aktivitas

Pada Proses Order Fulfillment

\begin{tabular}{|c|c|c|c|c|c|}
\hline Kode & Aktivitas & $\begin{array}{l}\text { Waktu } \\
\text { (Menit) }\end{array}$ & VA & NNVA & \\
\hline $1 \mathrm{~A}$ & Menerima form Replenish & 31,77 & 31,77 & & \\
\hline 1B & Mencetak Replenish Form & 3,56 & 3,56 & & \\
\hline $1 \mathrm{C}$ & Mencetak PTF & 5,95 & 5,95 & & \\
\hline 1D & Mencetak ID Part Terminal & 4,72 & 4,72 & & \\
\hline $1 \mathrm{~F}$ & Menyerahkan Form & 3,41 & & 3,41 & \\
\hline $2 \mathrm{~A}$ & Menuju Lokasi Rak & 2,71 & & 2,71 & \\
\hline $2 \mathrm{~B}$ & Mengambil material & 32,93 & 32,93 & & \\
\hline $2 \mathrm{C}$ & Meletakkan material ke stagging rak fix & 3,80 & 3,80 & & \\
\hline 2D & Memasukkan material ke rak fix & 3,68 & & 3,68 & \\
\hline $3 \mathrm{~A}$ & Menyiapkan Palet & 2,41 & 2,41 & & \\
\hline 3B & Menuju Lokasi Rak & 3,92 & & 3,92 & \\
\hline $3 \mathrm{C}$ & Mengambil material & 38,64 & 38,64 & & \\
\hline 3D & Meletakkan material ke stagging area & 2,05 & 2,05 & & \\
\hline $5 \mathrm{~A}$ & Mengecek material hasil picking & 4,22 & & 4,22 & \\
\hline $5 \mathrm{~B}$ & Mengecek kesesuaian sistem hasil scan & 13,17 & & 13,17 & \\
\hline $5 \mathrm{C}$ & Mencetak Delivery Note Check & 1,76 & 1,76 & & \\
\hline $5 \mathrm{D}$ & \begin{tabular}{|l|} 
Mengecek Delivery Note \\
\end{tabular} & 20,87 & & 20,87 & \\
\hline $6 \mathrm{~A}$ & $\begin{array}{l}\text { Membuat invoice \& mengirimkan data ke } \\
\text { PIC SAMI }\end{array}$ & 13,17 & 13,17 & & \\
\hline $6 \mathrm{~B}$ & Cetak invoice oleh PIC SAMI & 22,32 & 22,32 & & \\
\hline $7 \mathrm{~A}$ & \begin{tabular}{|l|} 
Menempelkan label invoice \& Mengecek \\
part number \& quantity
\end{tabular} & 20,92 & 20,92 & & \\
\hline $7 \mathrm{C}$ & Mengemas material (wrapping) & 20,23 & 20,23 & & \\
\hline $8 \mathrm{~A}$ & $\begin{array}{l}\text { Mengambil material menggunakan counter } \\
\text { balance }\end{array}$ & 0,47 & & 0,47 & \\
\hline $8 \mathrm{~B}$ & Meletakkan material ke dalam kontainer & 10,21 & 10,21 & & \\
\hline $8 \mathrm{C}$ & $\begin{array}{l}\text { Membuat surat jalan \& menyerahkan ke } \\
\text { driver }\end{array}$ & 13,14 & 13,14 & & \\
\hline & $\begin{array}{ll}\text { Total Waktu } \\
\end{array}$ & 280,03 & 227,58 & 52,45 & $\mathbf{0 , 0 0}$ \\
\hline
\end{tabular}

Berdasarkan Tabel 6 dapat diketahui bahwa total aktivitas setelah dieliminasi menjadi 24 aktivitas dari 34 aktivitas. Total waktu sebelum direduksi adalah 427,95 menit dan setelah direduksi menjadi 280,03 menit.

\subsection{Membuat Future State Map (FSM}

Future State Map merupakan gambaran value stream mapping setelah dilakukan eliminasi waste, serta digunakan untuk mengetahui seberapa besar perubahan yang terjadi. Pembuatan future state map dilakukan berdasarkan hasil aktivitas yang telah dieliminasi dan waktu yang telah didireduksi. Berikut ini future state map dapat dilihat pada Gambar 4

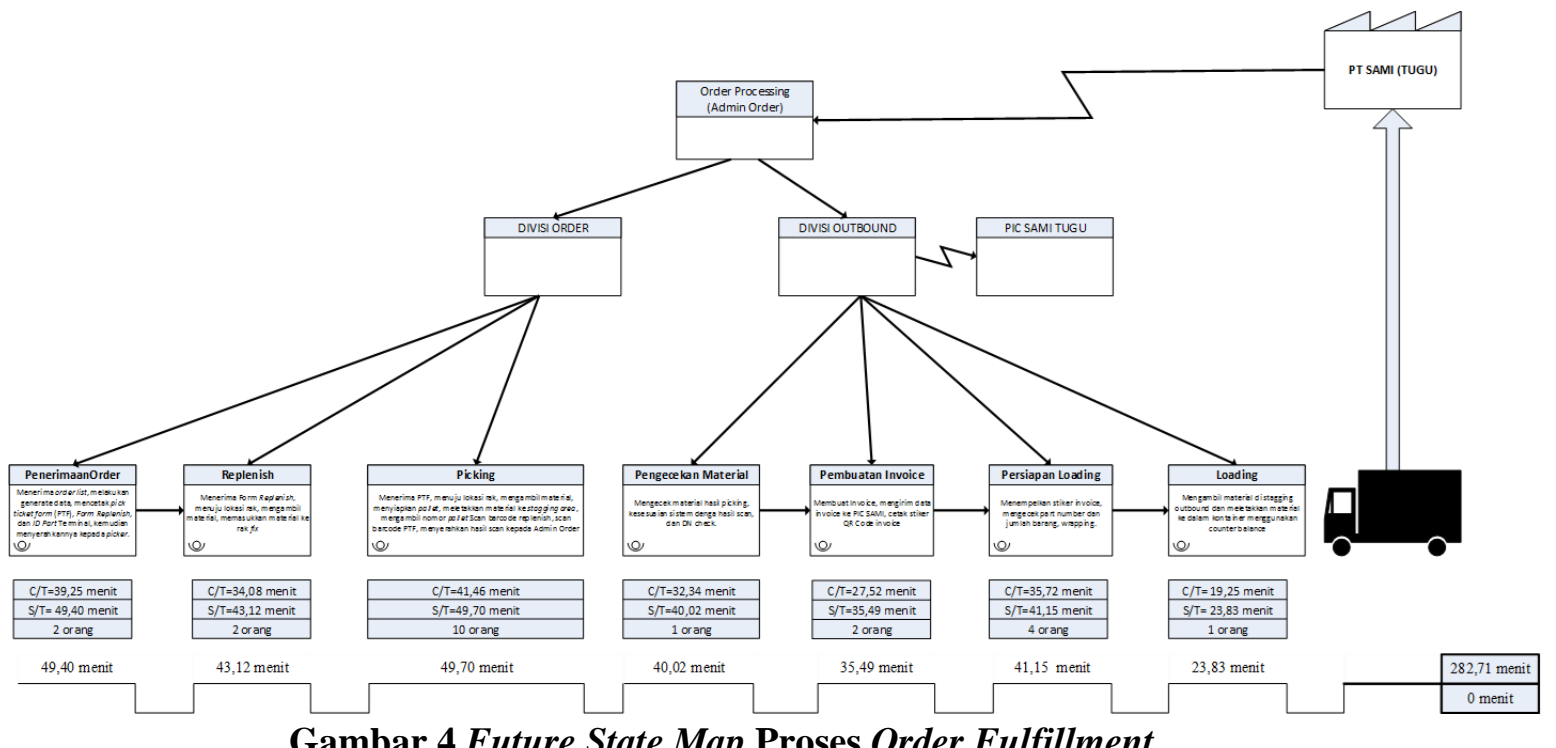

Gambar 4 Future State Map Proses Order Fulfillment 
Berdasarkan future state map yang digambarkan pada Gambar 4.5, terdapat perbaikan berupa penghilangan proses scan. Penghilangan proses ini dikarenakan proses tersebut dapat disatukan dengan proses sebelumnya yaitu proses picking. Setelah picker mengambil barang dan meletakkannya ke stagging area picker dapat langsung melakukan scan pada PTF. Hal ini dapat mengefektifkan waktu karena proses menjadi lebih cepat karena tidak menunggu antrian PTF selesai discan oleh scanner. Selain itu, kita dapat mengetahui lead time proses order fulfillment di PLB PT Agility International setelah perbaikan adalah 282,71 menit. Total waktu untuk masing-masing aktivitas value added (VA) adalah sebesar 227,58 menit, dan aktivitas non-value added (NVA) tidak ada karena sudah dihilangkan.

\subsection{Rekomendasi Perbaikan}

Rekomendasi perbaikan dilakukan dengan menggunakan Metode Kaizen dengan mengimplementasikann 5S (Seiri, Seiton, Seiso, Seiketsu, Shitsuke).

\section{Seiri (Sort)}

Penerapan seiri (pemilahan) yang dapat diterapkan antara lain dengan cara menyimpan atau melakukan pemilahan peralatan yang tidak terpakai pada lini produksi seperti melakukan pemilahan berkas pemeriksaan material, pemilahan pallet, pemilahan kardus bekas material, pemilahan paper core wire dan item lain yang akan digunakan dan tidak digunakan.

\section{Seiton (Stabilized, Straighten, Set in order, Simplify)}

Penerapan seiton yang dapat dilakukan adalah dengan melakukan penataan terhadap tempat penyimpanan peralatan yang akan digunakan dalam produksi, contohnya adalah menyimpan peralatan seperti gunting, plester, plastic wrap dalam satu tempat yang mudah dijangkau. Selain itu, dengan mengidentifikasi dan memberikan label atau tanda pada bin penyimpanan tersebut, dapat memudahkan setiap orang untuk menemukan item-item tersebut. Hal ini bertujuan untuk menghilangkan proses pencarian yang akan menghabiskan waktu sehingga pekerjaan menjadi lebih efisien.

\section{Seiso (Shine, Sweep)}

Perusahaan perlu membuat suatu jadwal untuk melaksanakan house-keeping dan penanggung jawabnya dalam pembersihan area produksi keseluruhan secara berkala, minimal 1 minggu sekali. Sedangkan untuk pembersihan di stasiun kerja masingmasing, pekerja membersihkan area kerjanya/meja sebelum dan sesudah jam kerja. Perusahaan juga harus membuat prosedur untuk melaksanakan proses shine harian secara terus menerus. Selain itu, tetapkan inspeksi secara reguler untuk mempertahankan kontinuitas shine targets untuk peralatan, handling tools, komputer, furniture dll.

\section{Seiketsu (Standarize)}

Penerapan seiketsu dapat dilakukan dengan cara sebagai berikut:

1. Memastikan tempat kerja selalu rapi.

2. Memeriksa bila terdapat barang yang tidak diperlukan yang masih tertinggal setelah pelaksanaan order fulfillment.

3. Pemeriksaan terhadap tempat penyimpanan dan memastikan apakah semua material dan handling tools sudah tersusun secara rapi.Memastikan susunan tempat penyimpanan sesuai dengan daftar penyimpanan dan urutannya.

4. Pemeriksaan terhadap debu dan kotoran pada tiap meja produksi.

\section{Shitsuke (Sustain, Self-Discipline)}

Hal yang dapat dilakukan pada metode shitsuke antara lain dengan memasang slogan, pengumuman atau foto pada lingkungan kerja sesuai dengan program 5S. Kemudian perlu dilakukan audit untuk program 5S minimal satu bulan sekali. Hal ini dilakukan untuk dapat mengevaluasi implementasi program $5 \mathrm{~S}$ sehingga program 5S dapat berjalan dengan baik dan mengalami peningkatan. 


\section{KESIMPULAN}

Hasil analisis identifikasi current state map menunjukkan aktivitas value added sebanyak 18 aktivitas dengan total waktu 230, 95 menit, aktivitas non value added sebanyak 3 aktivitas dengan total waktu 117,03 menit, dan aktivitas neccessary non value added sebanyak 9 aktivitas dengan total waktu 79,45 menit. Hasil analisis Waste Assessment Model (WAM) menunjukkan bahwa waste dengan persentase tebesar adalah waste duplication dengan persentase sebesar $12,07 \%$, dan waste transportation dengan persentase sebesar 9,50. Waste dengan persentase terbesar merupakan waste kritis (paling berpengaruh) yang terjadi pada proses order fulfillment PB PT Agility International.

Berdasarkan 5 why's analysis didapatkan akar permasalahan dari terjadinya pemborosan duplication, yaitu disebabkan oleh similar part pada material. Untuk memperbaiki hal tersebut perlu dibuat persamaan id part number agar memudahkan picker dalam membaca part dan mengambil material tersebut. Sedangkan akar permasalahan dari terjadinya permborosan transportation disebabkan oleh kurangnya komunikasi antar shift untuk membuat PTF (Pick Ticket Form), sehingga perlu adanya evaluasi dan penetapan jadwal pembuatan PTF dan replenish form. Selain itu, untuk meminimalisir terjadinya waste pada proses order fulfillment dapat dilakukan implementasi 5S (Seiri, Seiton, Seiso, Seiketsu, Shitsuke) di PLB PT Agility Interational (Semarang).

Adapun saran yang dapat diberikan penulis kepada perusahaan untuk perusahaan dalam melakukan perbaikan kualitas proses order fulfillment adalah Perusahaan seharusnya membuat persamaan id part number untuk meminimalisir kesalahan pada pengambilan material yang disebabkan oleh similar part dan mengakibatkan proses kerja dilakukan secara berulang-ulang (duplication).
Selain itu, perusahaan sebaiknya menghilangkan atau mengeliminasiaktivitas yang tidak bernilai tambah seperti pada aktivitas pengambilan replenish form \& PTF oleh Leader dan aktivitas menunggu. Replenish form \& PTF dapat dicetak pada shift terakhir dan dapat diserahkan langsung oleh Admin Order kepada picker setelah briefing, sehingga picker tidak perlu menunggu. Sedangkan untuk aktivitas yang tidak bernilai tambah namun diperlukan seperti scan barcode pada replenish form \& PTF dan penyerahan hasil scan, sebaiknya digabung dengan proses picking. Proses scan dapat dilakukan oleh picker karena dapat mengefektifkan waktu. Seluruh elemen perusahaan diharapkan lebih konsisten dan berkelanjutan dalam menerapkan $5 \mathrm{~S}$ yang menjadi landasan keselamatan kerja serta peningkatan produktivitas yang lebih baik.

\section{REFERENSI}

[1] Apple, J.M. 1990. Tata letak Pabrik dan Pemindahan Bahan. Edisi Ketiga. Bandung: ITB

[2] Gazperz, Vincent. 2007. Lean Six Sigma for Manufacuring and Service Industries. Jakarta: Pt Gramedia Pustaka Utama.

[3] Handayani, Naniek U. \& Renaldi, Stellya V. 2018. Analisis Waste Pada Proses Unloading Kayu Log Dengan Pendekatan Lean Service Pada Terminal Nusantara Pelabuhan Tanjung Emas PT. Pelabuhan Indonesia III (Persero). Departemen Teknik Industri, Fakultas Teknik, Universitas Diponegoro

[4] Hines, Peter \& Taylor, David. 2000. Going Lean. Lean Enterprise Research Centre. Cardiff Bussiness School. Cardiff (UK)

[5] Ishak, Aulia. 2010. Manajemen Operasi. Yogyakarta: Graha Ilmu.

[6] Kementerian Keuangan. 2015. Peraturan Menteri Keuangan No.272 tentang Pusat Logistik Berikat. Jakarta: Kementerian. 
[7] Lópeza, E. Andrés-I., GonzálezRequenaa, \& A. Sanz-Loberaa. 2015. Lean Service: Reassessment of Lean Manufacturing for Service Activities. Procedia Engineering 132 (Page: 23 30)

[8] Martono, Ricky. 2015. Manajemen Logistik Terintergrasi. Jakarta: Penerbit PPM.

[9] Permadi, Dodi \& Okdinawati, Liane. 2016. Buku ajar Manajemen Pergudangan. Penerbit CV Budi Utama: Yogyakarta

[10] Rawabdeh, Ibrahim, A. 2005. A model For Assessment of Waste In Job Shop Enviroment. International Journal Of Operations \& Production Management, Vol 25

[11] Rozid, Abdur. 2017. Perkembangan Pesat Tahun Pertama Pusat Logistik Berikat, (Online),

[12] (https://www.kemenkeu.go.id/publik asi/artikel-dan-opini/perkembanganpesat-tahun-pertama-pusat-logistikberikat/, diakses 27 Juni 2019).

[13] Shalihin, Ahmad \& Hidayati, Juliza. 2019. Measurement of quality of certification services to reduce wastage of non value added activity (journal review). IOP Conference Series: Materials Science and Engineering.

[14] Shodiq, Muhammad A. K. \& Haryono. 2014. Analisis Penerapan Lean Manufacturing untuk Mengilangkan Pemborosan di Lini Produksi PT Adi Satria Abadi. Jurusan Tekologi Industri. Universitas Pembangunan Nasional Veteran.

[15] Sugiyono. 2015. Metode Penelitian Pendidikan (Pendekatan Kuantitatif, Kualitatif dan R\&D). Penerbit CV. Alfabeta: Bandung.

[16] Sumanth, David J. 1998. Total Productivity Management. New York: A CRC Company

[17] Sutalaksana, dkk. 2006. Teknik Perancangan Sistem Kerja. Edisi Kedua. Bandung: ITB

[18] Sutarman. 2017. Dasar-dasar Manajemen Logistik. PT Refika Aditama: Bandung.

[19] Tangkilisan, Nogi Hessel. 2005. Manajemen Publik. PT. Gramedia Widiasarana Indonesia : Jakarta.

[20] Wilson, Lionnie. 2010. How to
Implement Lean Manufacture. The McGraw-Hill Companies, Inc.

[21] Womack, James P. \& Jones, Daniel T. (2003). Lean Thingking, Banish Waste and Create Wealthin Your Corporation. Simon\& Schuster UK Ltd. 